\title{
Design errors of the external lift shaft and their negative impact on the operation of the clinic building
}

\author{
Maciej Niedostatkiewicz ${ }^{1,{ }^{*}}$, Tomasz Majewski ${ }^{2}$, and Patryk Ziółkowski ${ }^{1}$ \\ ${ }^{1}$ Gdansk University of Technology, Faculty of Civil and Environmental Engineering, Department of \\ Concrete Structures, G. Narutowicza 11/12, 80-233 Gdansk, Poland \\ ${ }^{2}$ Pracownia Projektowo - Inżynierska Tomasz Majewski, Osiedle Sierakowskich 9B/3, \\ 82-400 Sztum, Poland
}

\begin{abstract}
Three-story external lift shaft was added to the gable wall of the existing clinic building. The shaft was designed as an independent static system, not connected to the building structure. After three years of operation, an increase in the width of the expansion joints between the building's top wall and the shaft at its entire height was found. The defects most likely can be addressed to subsidence of land accompanied by changes in the level of groundwater within the foundations of the building. In this paper, we proposed a solution to repair the defect and restore the proper technical condition allowing for its continued safe use.
\end{abstract}

\section{Introduction}

Design and implementation errors have a significant impact on the overall safety of the structure. What is more, the wrong exploitation very often contributes to the occurrence of defects or deepening existing ones [1-2]. Renovations in general, especially in public facilities are usually carried out as periodical repair works to maintain facilities in a permissible technical condition. Repairs are aimed at removing the pre-emergence or emergency conditions and increasing the operational standard of the facility when there is a need to do so. The fact that these facilities must be used in most cases continuously hinders repairs of defects caused by both incorrect design and construction works [3-9]. This paper aims to present the impact of design errors on the safety and reliability of the structure. The paper also presents a design solution for removing the identified defects.

\section{General information}

After 25 years of service, the clinic building was adapted to serve people with disabilities. The external lift shaft [Fig.1 and Fig.2] was made based on individually developed project documentation. The shaft's construction began 25 years after the completion of the clinic building. It has been adapted to the needs of people with motion dysfunction. The shaft is a

\footnotetext{
${ }^{*}$ Corresponding author: mniedost@pg.gda.pl
} 
masonry structure, made of hollow clay bricks, with horizontal battens in the form of reinforced concrete, monolithic wreaths made in the level of ceilings above the ground floor and over the first floor of the clinic. The clear internal dimensions of the shaft are $158 \times 190 \mathrm{~cm}$, while the clear external dimensions are as follow $196 \times 228 \mathrm{~cm}$. The shaft is placed on a reinforced concrete foundation slab with a thickness of $25 \mathrm{~cm}$ and external dimensions the same as of the elevator shaft. The underground part of the shaft is made from reinforced concrete with dimensions $19 \times 120 \mathrm{~cm}$ up to ground level. The cover of the shaft is non-ventilated flat roofs, whose load-bearing structure is a reinforced concrete monolithic slab with a thickness of $8 \mathrm{~cm}$, insulated and secured with a roofing membrane [Fig. 3 and Fig.4]. Three years after completion first defects occurred. We observed with the naked eye the detachment of the shaft structure from the building's gable wall which ranged from around $2 \mathrm{~mm}$ at the ground floor to about $8 \mathrm{~mm}$ on the second floor. We were notified that during the use of the lift there were cyclical stops of the moving elevator, which caused significant difficulties in the functioning of the clinic. As part of ongoing renovation works, the rifts were filled with a rigid sealing material. In the period of further exploitation at the level of the shaft along the wall contact (passenger lift and building top wall), hairline cracks were still formed which widened to a width of $1 \mathrm{~mm}$ over time. The user successively masks visible scratches covering them with filler methods.

a)

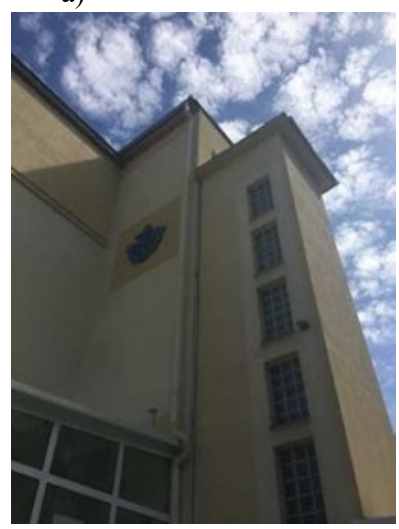

b)

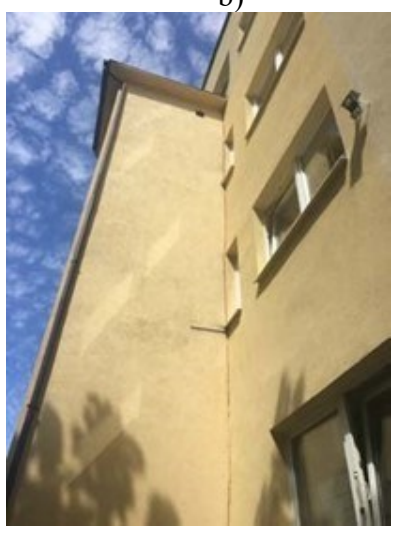

c)

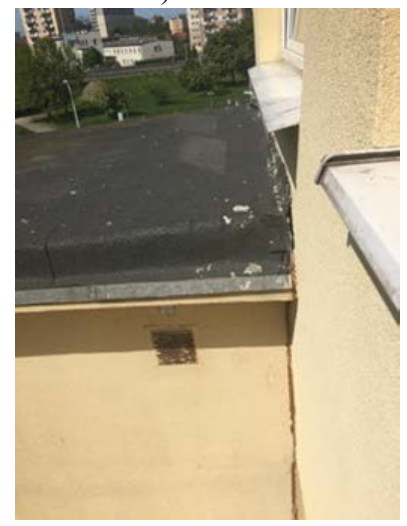

Fig. 1. External lift shaft located next to the clinic: a) front-view, b) courtyard-view, c) rooftop view.

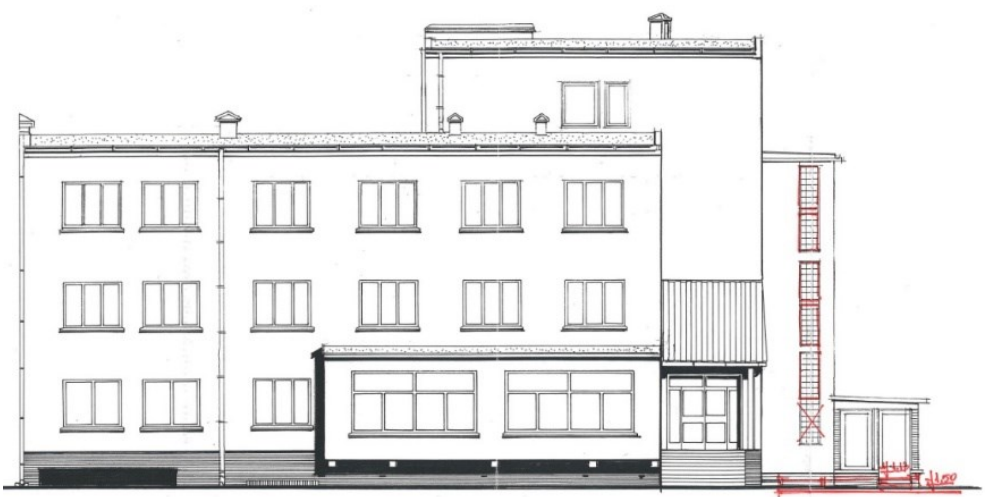

Fig. 2. Front facade of the clinic. External lift shaft is visible on the right-hand side of the image. 


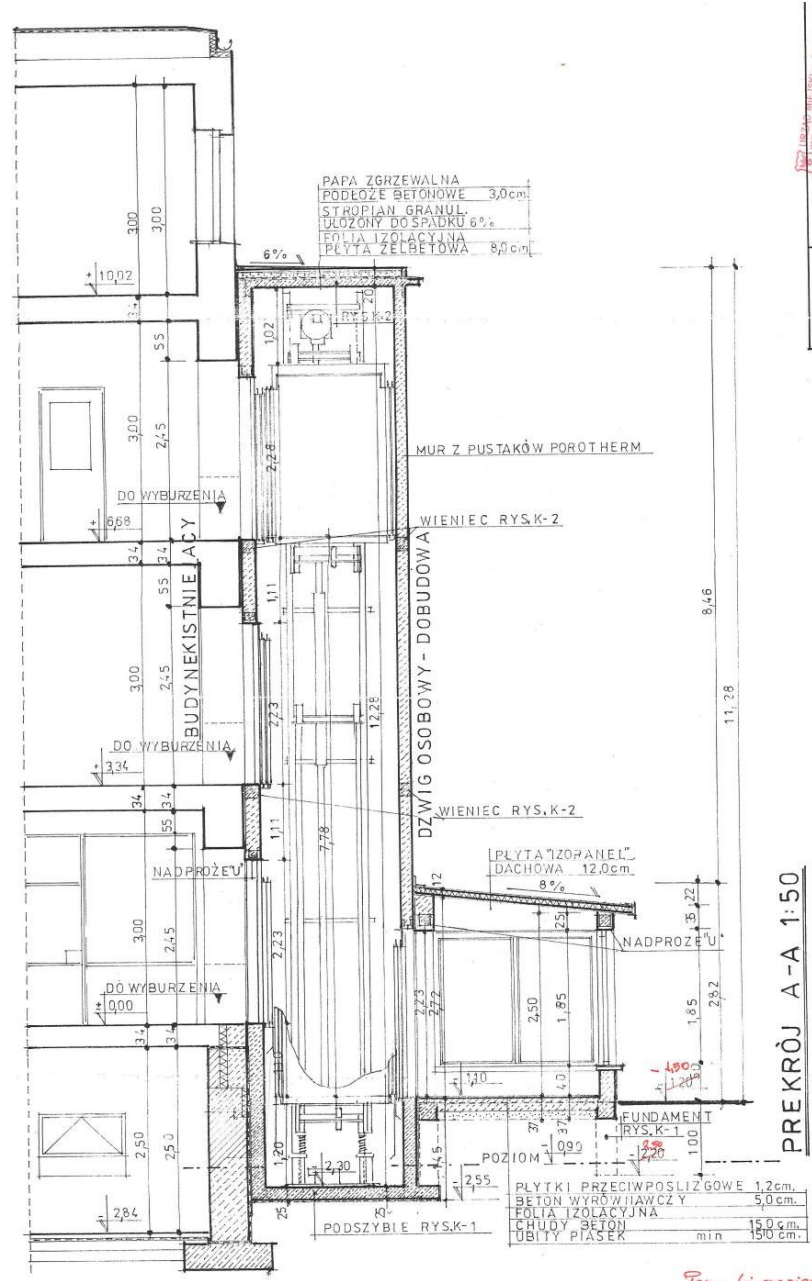

Fig. 3. Vertical cross-section of the external lift shaft. 
a)

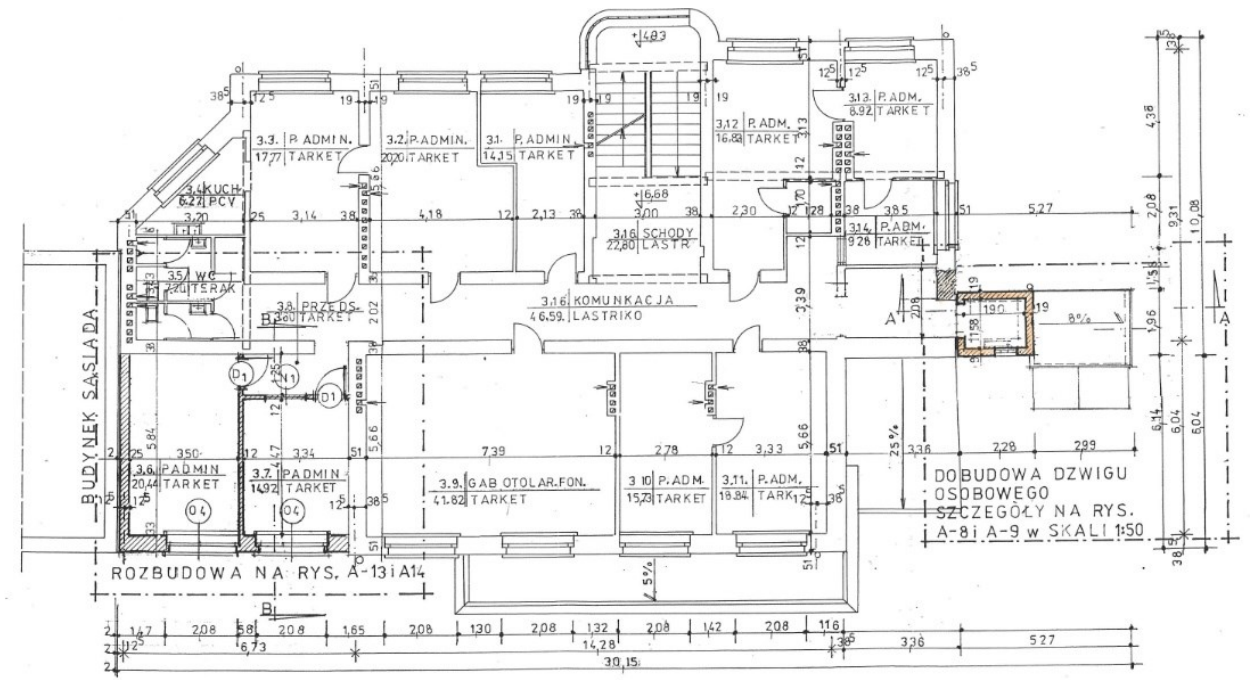

b)

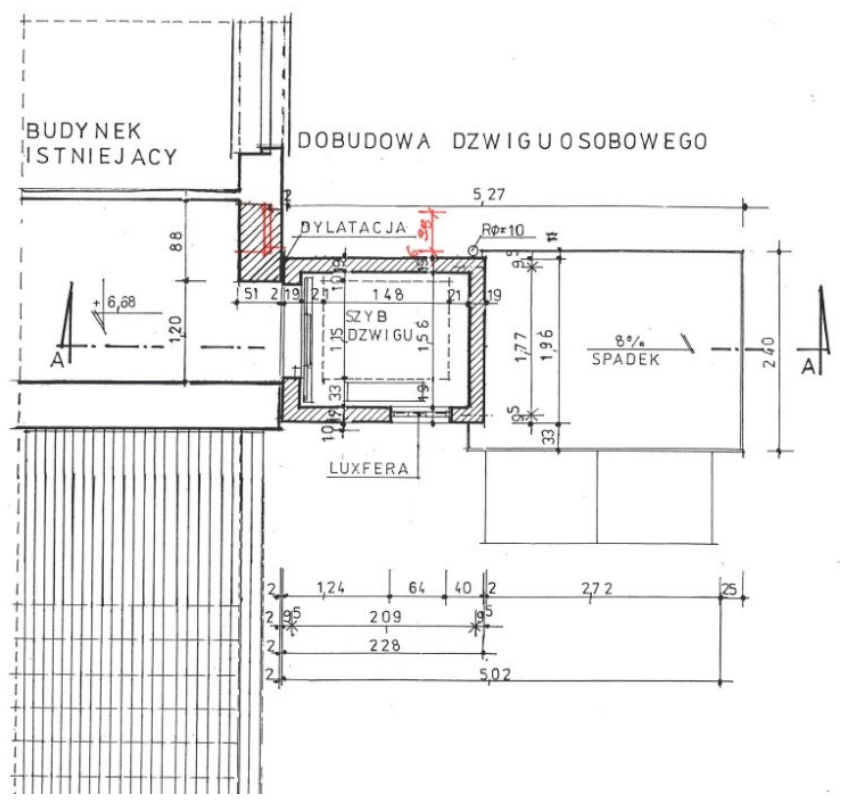

Fig. 4. External lift shaft located next to the clinic: a) second-floor plan, b) shaft detail. 


\section{Description of the existing conditions}

Near the clinic building, tall trees grow, in particular at its gable wall to which the lift shaft is added. The area around the building is hilly, the pavement is made of hexagonal concrete cubes and unevenly deformed, locally sunken from the yard and car parking side. In the depression of the surface, water stagnation is forming during atmospheric precipitation, which instead of flowing into the wells gravitationally soaked into the soil under the sidewalk. A year before the construction of the external lift shaft the building owner made an external tubular drain around the building and internal drain inside, which is along the basement corridor, to lower the groundwater level in the outline of the building. Both internal and external drains are connected via intermediate wells. One of these wells is located at the top of the building near the elevator shaft, and two others in the basement corridor at the opposite gable walls. The outer well-acted as a gathering tank, to which water collected by an external and internal drain is drifting down. Water from this well discharge into the city's rainwater sewage system. Electric float pump controls the water level automatically and turns on at the marked out rainwater level in the well. These gaps were partially filled with elastic material, which was laid during repairs. The filler material (of various types) did not fill the gap on the wall thickness, while the surface was loose from the ground. We observed unfilled expansion joints on the facade of the building, at the contact between the building block and the shaft. These expansion joints are partially filled with elastic material, laid during repair works. The filling material did not fill the gap on the wall thickness. It is standing out from the surface. We noticed cracks in the following areas, from the interior side, on the entire height of the building, in the ground floor, first and second floor, at the junction of the gable wall and the lift shaft. The width of the cracks increased along with the height of the building: from the capillaries in the basement level to about $1.0 \mathrm{~mm}$ in the second-floor level. At the first floor, the crack width did not exceed $0.5 \mathrm{~mm}$.

\section{Analysis of the existing conditions}

\subsection{Construction and material solutions}

The designer made a foundation for the external lift shaft as an open reinforced concrete box consisting of a foundation slab with a thickness of $25 \mathrm{~cm}$ and pedestal $(19 \mathrm{~cm}$ thick, $120 \mathrm{~cm}$ high). He used concrete B15 according to [4], which corresponds approximately to class C12/16 according to the current standard [6], reinforced with class A-III bars (34GS), which roughly corresponds to the class A ductility according to PN-EN 1992-1 -1 [6] and stirrups of class A-0 (St0S), of which Eurocode 2 [6] does not include. At present, StOS steels do not apply to the reinforcement of reinforced concrete structures according to [6]. Above, the walls are made of hollow clay bricks $19 \mathrm{~cm}$ thick, on M-7 mortar. However, he did not specify the compressive strength of the bricks and did not indicate the details of the connection between the foundation slab and the plinth wall. In our opinion, it was possible to do it by concreting the omega sealing tape in the working gap, at the contact surface. From the top, the elevator shaft is covered with a reinforced concrete slab and non-ventilated flat roof on it. The thickness of the slab is $8 \mathrm{~cm}$, a concrete class is B15 and reinforcement steel class A-III (34 GS). In the backrest of the plate on the walls level is a perimeter ring beam, $19 \times 25 \mathrm{~cm}$ dimensions, reinforced with A-IIIN class bars (34GS) and A-0 class stirrups (StOS). The roof is insulated with foamed polystyrene, with the layer of inheritance and the waterproofing membrane. Around the flat roof is a cornice and mounted sheet metal work. At the level, which is between the first and second floor, are reinforced concrete perimeter ring beams $19 \times 25 \mathrm{~cm}$. 
We conclude that they increase the spatial stiffness of the shaft. Concrete and steel are the same as for the foundation. We noticed that in the archival design documentation, the reinforcement of ring beams, which due to the shape of the reinforcement, do not ensure full bilateral bracing of reinforcing bars in the corners. The difference in the foundation levels of the elevator shaft and the foundations of the building is around $1.0 \mathrm{~m}$. We believe that the main reason for the uneven settlement of the elevator shaft structure is the shape of the foundation slab, which partially overlap with the building footing. In the adopted solution, the distribution of stresses in the soil medium and its deformation is not uniform on the width of the slab. The reinforced concrete offset of the foot as a stiffer element than the foundation slab caused the shaft rotation to the edge of the exterior wall of the building [11].

The project assumed a total lack of interaction between the body of the existing building and the added lift shaft when transferring loads. According to the design, the shaft should be self-stable (have so-called global stability), which is a correct assumption. However, the proposed and implemented solution resulted in an uneven settlement of the ground under the foundation slab of the shaft, which caused rotation of the entire shaft and the formation of cracks with variable width at the point of contact with the building. The users of the building during several years of observation stated that the cracks are widening with the increase of the height above the ground level.

\subsection{Ground and water conditions}

On the basis of soil tests results, which are an integral part of the archival project documentation, we determined that the following layers of soil were located under the lift shaft [11]: to the depth of $1.3 \mathrm{~m}$, uncontrolled embankments $(1.1 \mathrm{~m}$ in thickness, under that there is a weak-layer of peat with sand, in the plastic state, the thickness is about $0.5 \mathrm{~m}$ ) and fine sand in the medium compacted state. The drilled groundwater level is $1.8 \mathrm{~m}$ below ground level. The designed level of the foundation slab is 1.35 below ground level. The slab is designed a $10 \mathrm{~cm}$ layer of lean concrete class B7,5, which mean that the shaft is placed on a compressible peat layer with a thickness of $0.35 \mathrm{~m}$.

There was no possibility to determine whether the existing drains: outer band and inner, were made by the developed project documentation or were implemented cost-efficient. Likewise, there was no clear information, whether the applied solutions took into account the type of subsoil that surrounds the clinic building, as well as whether its permeability (socalled flow expenditure) was taken into account during the drainage process.

The number and type of plantings (trees) located around the clinic building allow formulating the thesis that the existing drainage tubing, as well as the immediate vicinity of the trees, caused cyclical changes in soil humidity around the foundation of the elevator shaft, resulting in its uneven settlement.

\subsection{Influence of trees and vegetation}

In the area adjacent to the clinic building, near the lift shaft, leafy trees grew, whose crown top reached the level of the ceiling above the second floor. According to the generally accepted engineering practice, the range of trees influence is approximately equal to their height, which meant that these trees could hurt the fragment of the clinic building to which the outer passenger lift shaft adhered. This influence consisted in changing the humidity of the soil at the roots of the tree and pushing the soil through the growing roots, which caused the pushing (foundation) of the lift shaft foundations [12]. 


\subsection{Impact of transit traffic}

The building of the clinic was located near a significant transport hub, which is a tramway track and an urban transit road burdened with heavy traffic of heavy motor vehicles [13-15]. We analysed the morphology of existing damage as a whole, and it could not be clearly stated that they arose as a result of vibrations transmitted through the ground substrate whose source is the movement of vehicles. There was also no vibration of the shaft felt by man.

\section{Repair concept}

As part of the renovation works of the external lift shaft, it was proposed:

- reinforcement of the subsoil under the foundation slab of the lift shaft through the use of pressing piles (from prefabricated, system steel elements). This method consists of cutting in the ground (pressing in) sections/parts of steel pipes and then performing their injection with cement grout. It was recommended to make four piles with an outside diameter of a $16 \mathrm{~cm}$ or $20 \mathrm{~cm}$ steel pipe reinforced with $16 \mathrm{~mm}$ (4Ø16) diameter rods made of AIII-N grade steel. After the piles are made, they must be anchored in the foundation plate of the shaft. The space between the steel pile and the bottom of the foundation slab should be sealed with cement injection. Due to the location of the building and the level of groundwater, it was necessary to take into account the need to make an additional hole in the foundation slab for drainage of groundwater by pumping (to equalise pressure). The location of the piles had to be adapted to the position of existing fender devices fixed in the bottom of the elevator shaft. Concepts for the ground reinforcement design solution using steel staple punches are shown in Fig. 5, which shows two variants of the location of piles and the method of anchoring a single pile in a foundation plate of a lift shaft (Fig.6),

- after reinforcement (piling), the shaft of the elevator lift shaft in the level of ceilings above the ground and first floor had to be connected to the building block of the clinic by steel clamps. The clamps would be fastened to the ceilings of the building and to the reinforced perimeter rims made at the level of the shaft of the elevator shaft (Fig.7),

- cutting down trees located in the area adjacent to the clinic building and in the area adjacent to the fence around the building in the vicinity of the shaft in question. The trees had to be removed along with the roots, and the excavations filled with the sand mixture and mechanically thicken. It was not necessary to use cohesive soil (impermeable) to backfill excavations after removed roots,

- existing solutions of drains (external and internal) after cutting out trees and carrying out the proposed scope of repair works should have been left as imperfect, which do not have a negative impact on the foundation of the lift shaft,

- checking the technical condition of pumps installed in wells, whose task was to reduce the level of groundwater in the area around the clinic building. In the case of irregularities in the operation of the pumps, they had to be repaired or replaced. 
a) option I

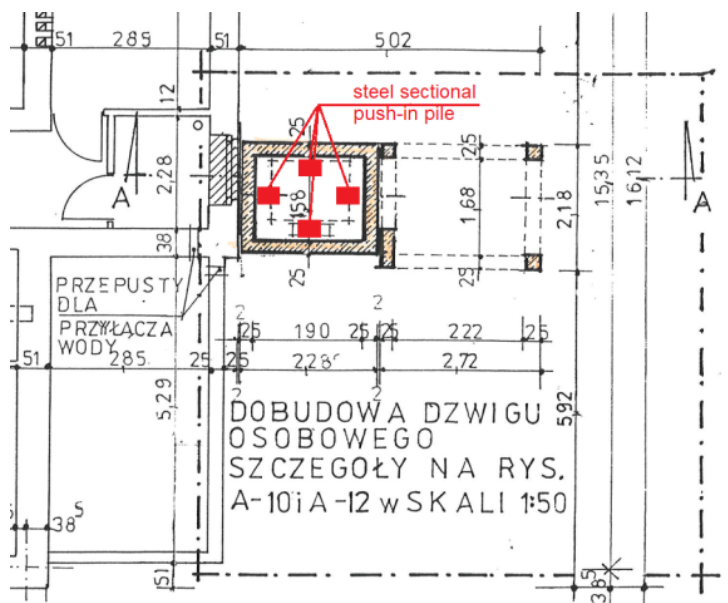

b) option II

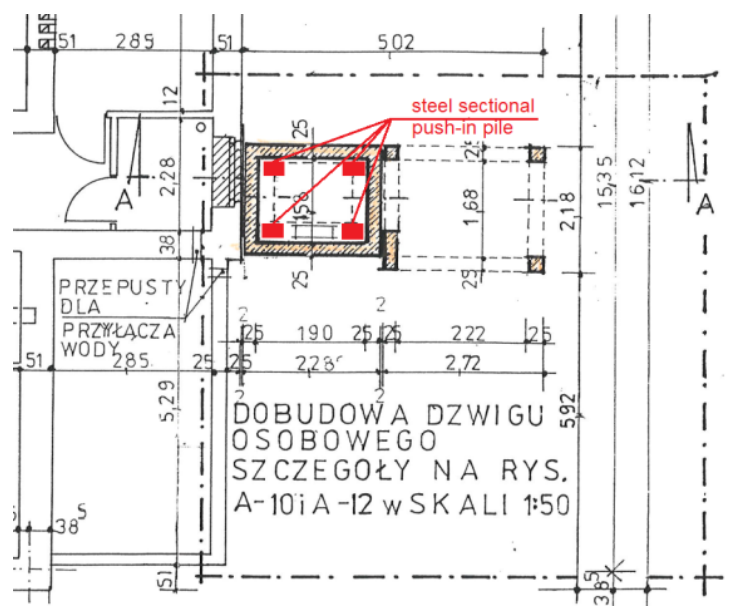

Fig. 5. The concept of a ground reinforcement design solution under the outer passenger lift shaft at the clinic building with the use of steel stapled pressing piles: a) option I, b) option II. 


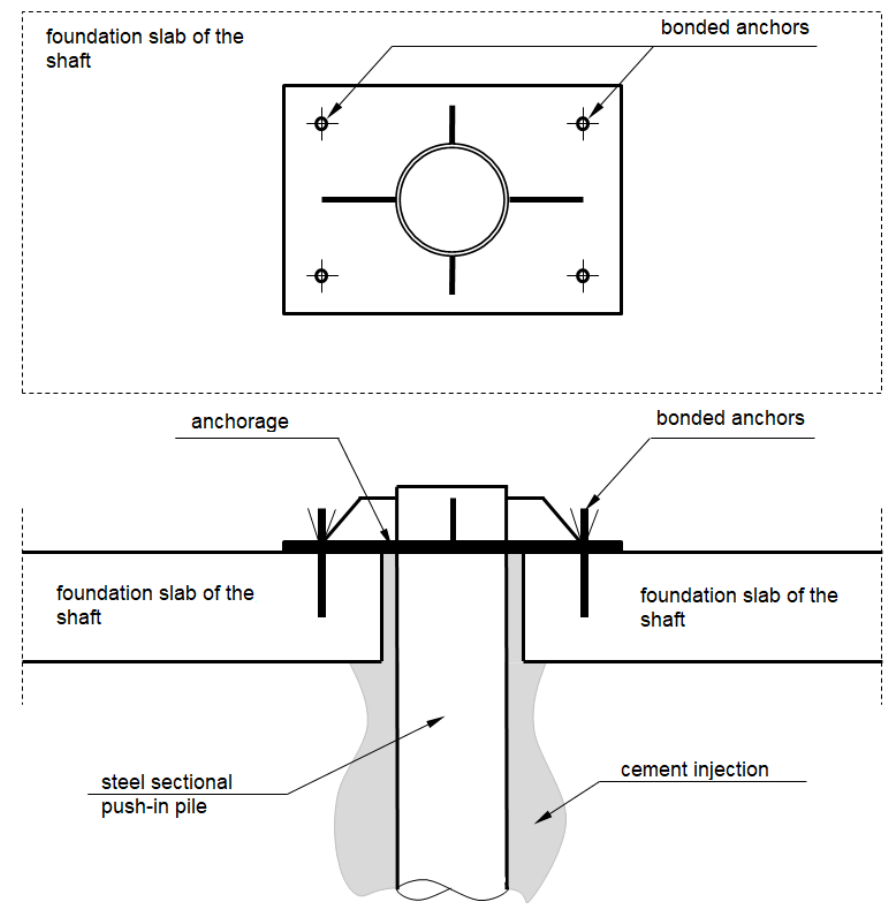

Fig. 6. The concept of a design solution for anchoring steel staple piles pressed in the bottom plate of the external lift shaft at the clinic building.

\section{Conclusions}

The external lift shaft, which is attached to the existing building of the clinic, showed defects and damages consisting in opening the expansion joint along its entire height, made between the building's gable wall and the shaft walls. The width of the gap at the height changed during the exploitation of the shaft.

The immediate causes of damage were:

- imperfections of design solutions used during the construction of a passenger lift shaft consisting of:

* construction of the foundation slab above the existing foundations of the building,

* overlap of the foundation slab of the shaft on the offset of the existing foundation footing,

* lack of anchoring the elevator shaft in the level of floors between stories to the building structure, which would protect it against excessive leaning and buckling. The shaft was designed as independent support, which as a result of the uneven settlement of the ground (soil deformation) has tilted from the vertical and is subject to further displacement,

- construction and usage of drains: external and internal, which due to their location, i.e., how they are arranged vertically and horizontally, and height relative to the foundations of the building and the foundation slab of the shaft, cause changes in soil moisture and uneven settlement of foundations. 


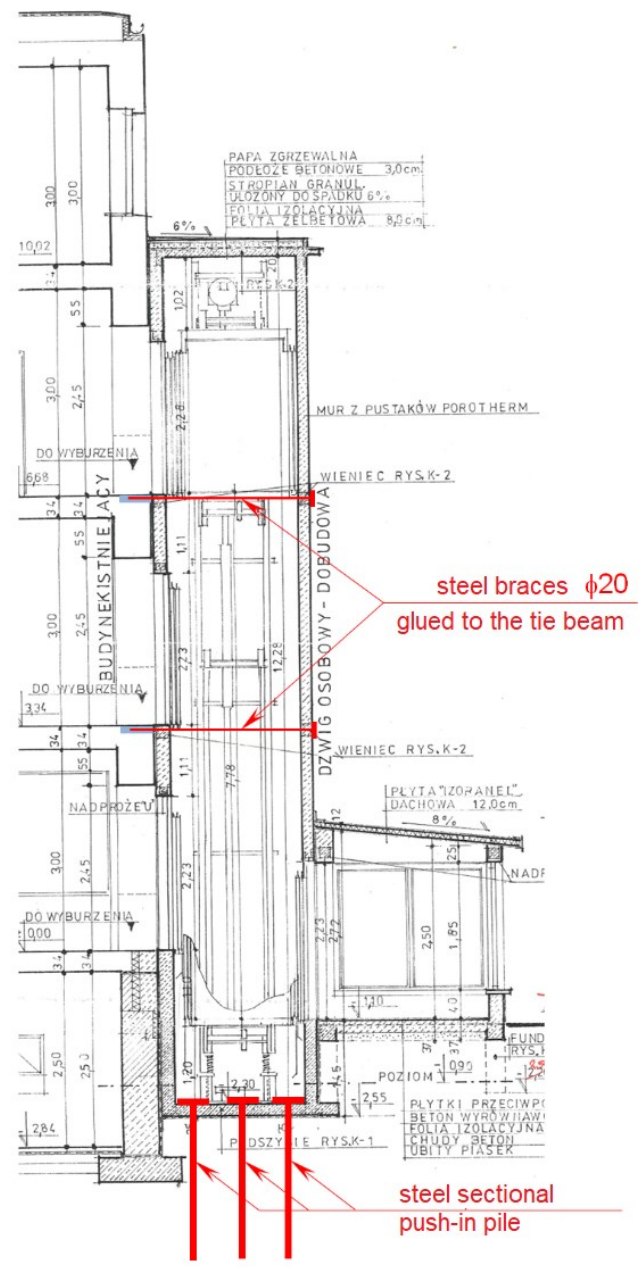

Fig. 7. The concept of the design solution of the external anchor of the passenger lift shaft with the shape of the clinic building. 


\section{References}

1. W. Baranowski, Zużycie obiektów budowlanych (Wydawnictwo Warszawskiego Centrum Postępu Techniczno-Organizacyjnego Budownictwa, Warszawa, 2000) [in Polish]

2. M. Substyk, Utrzymanie $i$ kontrola okresowa obiektów budowlanych (Wydawnictwo ODDK, Warszawa, 2012) [in Polish]

3. B. Bukowski, Archiwum Inżynierii Lądowej, 3(4) (1957) [in Polish]

4. Ł. Drobiec, R. Jasiński, Diagnostyka konstrukcji żelbetowych, tom 1 (Wydawnictwo PWN, Warszawa, 2010) [in Polish]

5. T. Urban, Wzmacnianie konstrukcji żelbetowych metodami tradycyjnymi (Wydawnictwo PWN, Warszawa, 2015) [in Polish]

6. G. Fegerlund, Trwałość konstrukcji betonowych (Wydawnictwo Arkady, Warszawa, 1997) [in Polish]

7. Joint publication, Trwałość i skuteczność napraw obiektów budowlanych (Dolnośląskie Wydawnictwo Edukacyjne, Wrocław, 2007) [in Polish]

8. E. Masłowski, D. Spiżewska, Wzmacnianie konstrukcji budowlanych (Wydawnictwo Arkady, Warszawa, 2000) [in Polish]

9. J. Thierry, S. Zaleski, Remonty budynków i wzmacnianie konstrukcji (Wydawnictwo Arkady, Warszawa, 1982) [in Polish]

10. PN-84/B-03264:2002, Konstrukcje betonowe, żelbetowe i sprężone -- Obliczenia statyczne i projektowanie [in Polish]

11. G. Wandzik, L. Szojda, A. Ajdukiewicz, Zabezpieczenie budynków w obszarach ujawniania się nieciagłości deformacji terenu (Proceedings of XXIII Scientific-Technical Conference on Structural Failures, Szczecin-Międzyzdroje, 2007) [in Polish]

12. J. Jeż, Przyrodnicze aspekty bezpiecznego budownictwa (Wydawnictwo Politechniki Poznańskiej, Poznań, 1998) [in Polish]

13. Guideline: Instrukcja ITB $n r$ 348/98, Diagnostyka dynamiczna i zabezpieczenia istniejacych budynków mieszkalnych przed szkodliwym działaniem drgań na właściwości użytkowe budynków (Wydawnictwo Instytutu techniki Budowlanej, Warszawa, 1998) [in Polish]

14. PN-85/B-02170:2016, Ocena szkodliwości drgań przekazywanych przez podłoże na budynki [in Polish]

15. PN-85/B-02171:2017, Ocena wpływu drgań na ludzi w budynkach [in Polish] 